\title{
Neural Tube
}

National Cancer Institute

\section{Source}

National Cancer Institute. Neural Tube. NCI Thesaurus. Code C34226.

A cylindrical structure formed by the longitudinal closure of the neural folds in the early embryo that will later differentiate into the brain and spinal cord. 